\title{
PERBANDINGAN KINERJA PORTOFOLIO SAHAM DI JAKARTA ISLAMIC INDEX DAN IDX30 PERIODE 2016-2018
}

\author{
Ami Adawiyah', Yudhia Mulya², Zul Azhar ${ }^{3}$ \\ 1,2,3 Universitas Pakuan, Bogor, Indonesia \\ Email Korespondensi: ${ }^{2}$ yudhiamulya@unpak.ac.id
}

\begin{abstract}
ABSTRAK
Penelitian ini bertujuan untuk mengetahui perbedaan antara kinerja portofolio saham Jakarta Islamic Index (JII) dan IDX30 periode 2016-2018. Jenis penelitian ini adalah penelitian verifikatif dengan metode explanatory survey dan menggunakan teknik statistik komparatif. Penelitian ini menggunakan metode analisis Markowitz dengan pendekatan minimum variance. Sampel yang digunakan adalah 189 saham Jakarta Islamic Index (JII) dan 200 saham IDX30. Hasil pengujian kinerja portofolio dengan menggunakan uji beda independent sample t-test, tidak terdapat perbedaan antara kinerja portofolio Jakarta Islamic Index (JII) dengan kinerja portofolio IDX30. Kemudian, dari hasil perhitungan Sharpe Ratio pada Jakarta Islamic Index (JII) dan IDX30 pada setiap periodenya bernilai positif. Hal ini menunjukkan bahwa portofolio dari kedua indeks selalu memperlihatkan kinerja yang bernilai positif atau baik. Implikasinya adalah tidak ada return tambahan yang dapat diperoleh investor dengan cara membedakan saham yang memiliki kiteria syariah dengan yang bukan syariah.
\end{abstract}

Kata Kunci: minimum variance; portofolio optimal; sharpe ratio

\section{ABSTRACT}

This study aims to determine the difference between the performance of the Jakarta Islamic Index (JII) and IDX30 stock portfolios for the 2016-2018 period. This type of research is a verification research with an explanatory survey method and using comparative statistical techniques. This research uses Markowitz analysis method with Minimum Variance approach. The sample used is 189 shares of Jakarta Islamic Index (JII) and 200 shares of IDX30. The results of portfolio performance testing using the independent sample t-test difference test, there is no difference between the performance of the Jakarta Islamic Index (JII) portfolio and the performance of the IDX30 portfolio. Then, from the results of the calculation of the Sharpe Ratio on the Jakarta Islamic Index (JII) and IDX30 in each period it is positive, this shows that the portfolios of the two indexes always show positive or good performance. The implication is that there is no additional return that can be obtained by investors by distinguishing stocks that have sharia criteria from those that are not sharia.

Keywords: minimum variance; portofolio optimal; sharpe ratio

KETERANGAN ARTIKEL

Riwayat Artikel: diterima: 27 September 2021; direvisi: 22 Desember 2021; disetujui: 25 Desember 2021

Klasifikasi JEL: G11, 016, P45

Cara mensitasi: Adawiyah, A., Mulya, Y., \& Azhar, Z. (2021). Perbandingan Kinerja Portofolio Saham di Jakarta Islamic Index dan IDX30 Periode 2016-2018. JIMFE (Jurnal IImiah Manajemen Fakultas Ekonomi), 7(2), $203-216$. https://doi.org/ 10.34203/jimfe.v7i2.3973

\section{PENDAHULUAN}

Dunia investasi berkembang sangat pesat, dengan bantuan teknologi yang semakin canggih dan modern sehingga dapat membantu para investor untuk menyediakan ruang yang cukup bervariasi dalam menanamkan modalnya. Pasar modal yang ada di Indonesia ialah Bursa Efek Indonesia (BEI) di mana 
terdapat berbagai jenis indeks harga saham seperti Indeks Harga Saham Gabungan, Indeks Sektoral, dan masih terdapat berbagai jenis indeks lainnya, seperti Indeks LQ45, IDX 30, Kompas 100, Indeks Bisnis 27, Indeks Pefindo 25, Indeks Sri-Kehati, Jakarta Islamic Index (JII), ISSI, Infobank15, SM Infra 18, M NC 36, dan indeks lainnya. Salah satu indeks yang dalam pemilihan sahamnya harus mengikut sertakan kiteriakiteria syariah ialah Jakarta Islamic Index (JII) sedangkan IDX30 merupakan indeks yang tidak mengikut sertakan kiteria-kiteria syariah dalam pemilihan sahamnya atau merupakan indeks non-Syariah, dilihat dari sisi kapitalisasi pasar indeks dengan kategori syariah memiliki nilai kapitalisasi pasar yang lebih kecil dari indeks non Syariah (Sutan, 2018).

Berdasarkan perkembangan return dan risiko IHSG, JII dan IDX30, terdapat perbedaan pola return dan risiko antara IDX30 dengan JII. IDX30 memiliki return dan risiko yang lebih tinggi dibanding dengan Jakarta Islamic Index (JII) dan IHSG. Dalam berinvestasi seringkali dilakukan pembentukan portofolio untuk memaksimumkan return yang didapat dan meminimumkan risiko yang harus ditanggung. Tujuan dari pembuatan portofolio optimal adalah untuk mengelola risiko. Risiko yang dihasilkan dari pembentukan portofolio yang optimal akan lebih rendah dibandingkan risiko dari sekuritas yang diinvestasikan secara individual. Diversifikasi portofolio dapat meminimalisir risiko dengan membentuk sebuah portofolio (Andriani \& Suprihhadi, 2015).

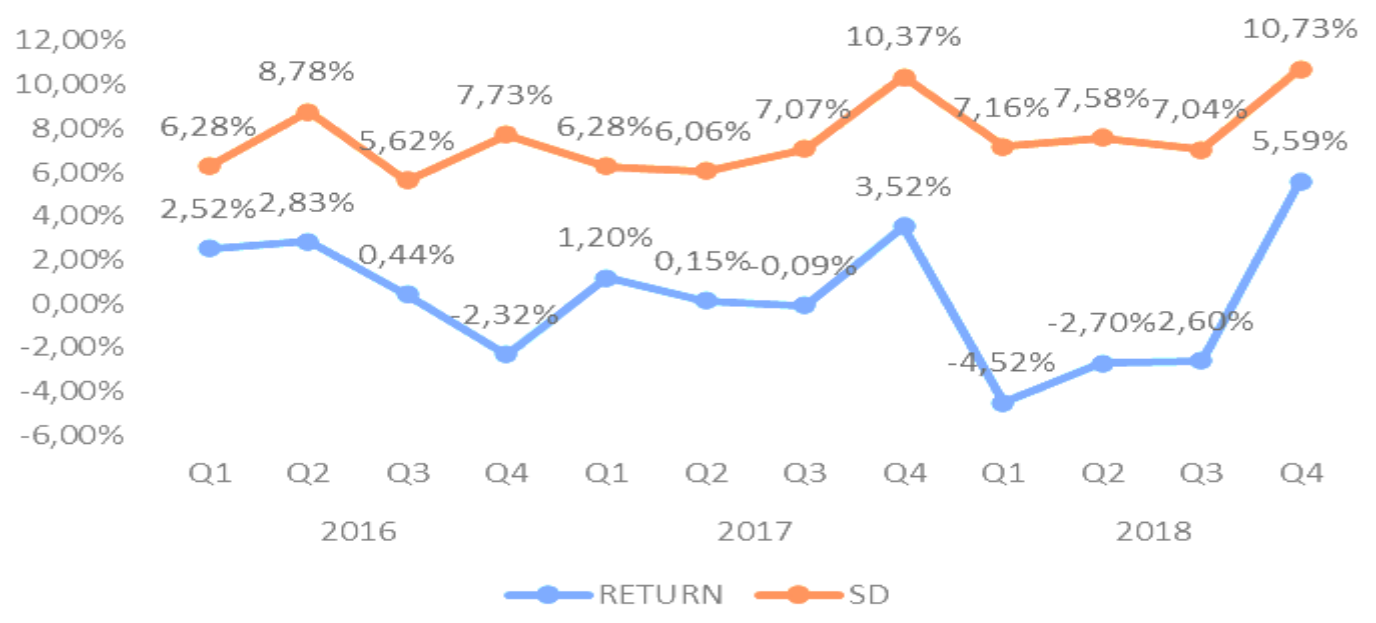

Sumber: IDX (2019)

Gambar 1. Grafik Rata-rata Return dan Risiko IDX30 periode 2016-2018

Pada Gambar 1 terlihat adanya fluktuasi return dan risiko pada 2016 hingga 2018. Pada periode Q4 2016, Q1 dan Q3 2017 serta Q3 2018 terjadi pergerakan yang tidak searah antara return dan risiko. 


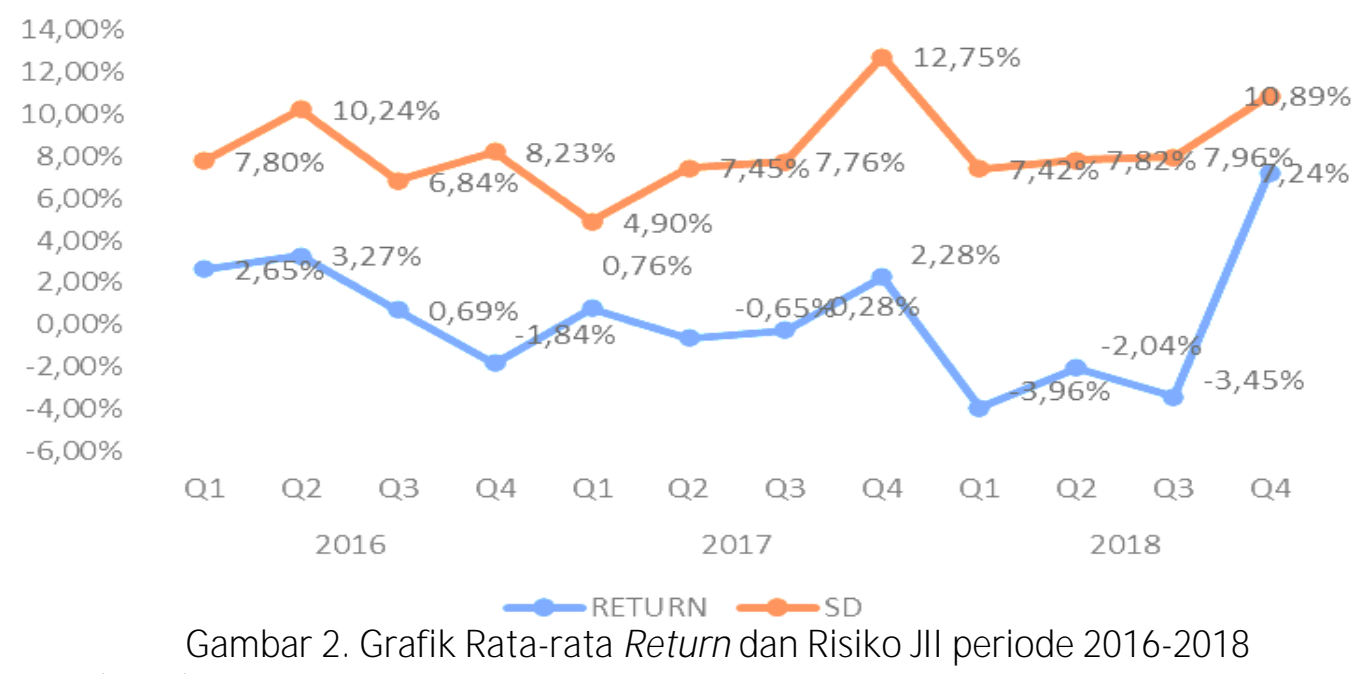

Sumber: IDX (2019)

Pada grafik rata-rata return dan risiko Jakarta Islamic Index (JII) di atas dapat dilihat pergerakan return dan risiko yang terjadi selama periode 2016-2018 yang tidak searah terjadi pada periode Q4 tahun 2016, periode Q1 dan Q2 tahun 2017 dan pada periode Q3 tahun 2018. Artinya, pada kedua grafik rata-rata Return dan Risiko Jakarta Islamic Index (JII) dan IDX30 periode 2016-2018 dapat disimpulkan bahwa return serta risiko pada tahun-tahun tersebut di atas bertolak belakang dengan teori yang dikemukakan oleh Hartono (2017). Hubungan positif antara return dan risiko menyebabkan makin besar return yang diterima maka risiko yang ditanggung pun akan makin besar.

Halim (2015) mengatakan investor melakukan pengukuran kinerja portofolio dari portofolio yang telah dibentuk dalam rangka untuk meminimalkan risiko yang ditanggung. Sharpe ratio merupakan salah satu pengukuran kinerja portofolio yang menekankan pada risiko total (standar deviasi). Kemudian, tingkat bunga bebas risiko juga merupakan poin penting dalam pengukuran kinerja portofolio, karena makin besar return yang dibentuk maka risiko yang harus ditanggung pun akan makin besar. Hal ini menjadi dasar perlunya keberadaan tingkat bunga bebas risiko terhadap pengukuran kinerja portofolio. Artinya, kinerja portofolio mempertimbangkan dua unsur, yaitu return dan risiko portofolio. Kedua hal tersebut harus sama-sama diperhatikan untuk menghasilkan kinerja portofolio terbaik.

Berdasarkan pertimbangan-pertimbangan investor dalam berinvestasi dengan membandingkan kinerja dari kedua indeks tersebut maka diperlukan penelitian lebih jauh terkait dengan bagaimana kinerja portofolio antara kedua indeks saham tersebut dengan analisis return, risk, dan kinerja portofolio JII dan IDX30 dengan menggunakan metode Sharpe Ratio sebagai salah satu faktor pertimbangan dalam berinvestasi.

\section{KAJIAN LITERATUR DAN PENGEMBANGAN HIPOTESIS}

Portofolio dibentuk dari berbagai kombinasi aset berisiko dan tidak berisiko yang terdapat di pasar modal yang bertujuan untuk membuat kombinasi yang efisien dari investasi aset tersebut sehingga investor dapat memperoleh return yang tinggi dan dapat mengurangi risiko dari investasi tersebut (Dahlan dkk., 2013). Pembentukan portofolio merupakan kegiatan membagi berbagai jenis usaha, dalam hal ini investasi, yang berarti juga membagi risiko investasi (Larasati dkk., 2013).

Jakarta Islamic Index (JII) ialah indeks yang memiliki tiga puluh anggota yang memenuhi kriteria syariah serta saham-saham yang tergabung ke dalam indeks ini memiliki tingkat likuiditas yang baik. 
Adapun IDX 30 merupakan indeks yang memiliki fundamental yang baik, likuiditas tinggi serta kapitalisasipasar yang besar. Investor dalam mengambil keputusan untuk berinvestasi selalu mempertimbangkan dua hal, yaitu return dan risiko. Investor juga melakukan pembentukan portofolio untuk meminimumkan risiko sehingga portofolio yang dibentuk adalah portofolio yang mampu mengkombinasikan return dan risiko terbaik yang sering disebut portofolio optimal (Hartono, 2017).

Model-model penilaian aset menjelaskan hubungan antara risiko dan pengembalian investasi yang diberikan dapat digunakan sebagai alat untuk mendukung pengambilan keputusan investasi (Sirucek \& Lukas, 2015). Dalam pembentukan portofolio optimal terdapat beberapa metode, salah satunya ialah metode Markowitz. M enurut Fahmi (2015) dasar dari model portofolio Markowitz adalah memberi bahan masukan kepada investor untuk menghindari risiko dan memberikan keuntungan yang maksimal pada setiap keputusan investasi. Pemilihan model Markowitz untuk membentuk portofolio optimal yang dipilih dari berbagai alternatif dari portofolio efisien, dapat memberikan pengembalian tertentu sesuai dengan risiko yang berani dihadapi oleh investor (Chandra \& Hapsari, 2013 \& Tuerah, 2013). Model Markowitz dapat menunjukkan portofolio sesuai dengan ciri-ciri investasi dan tujuan yang diinginkan (Natalia dkk. 2014).

\section{Pembentukan Portofolio Optimal dengan Model Markowitz}

Metode pengolahan data dalam penelitian ini adalah metode Markowitz. Teknik analisis data yang digunakan adalah menurut Hartono (2017), yang terdiri dari beberapa langkah sebagai berikut:

$$
R_{i t}=\frac{P_{i t}-P_{i t-1}}{P_{i t-1}}
$$

Pertama, menghitung return saham harian setiap perusahaan sampel. M enghitung return harian didapatkan dari Harga sekarang dikurangi harga sebelumnya dibagi harga sebelumnya.

$$
E R_{i}=\frac{\sum_{t=1}^{n} R i}{n}
$$

Kedua, menghitung expected return saham setiap perusahaan sampel yaitu jumlah return saham dibagi dengan periode waktu.

$$
\overline{A i}=\sqrt{\frac{\sum_{i=1}^{n}(R i t-E(R i))^{2}}{N-1}}
$$

Ketiga, menghitung standar deviasi saham, yaitu akar dari jumlah pengurangan antara return saham pada periode tertentu dengan expected return dikuadratkan dibagi jumlah periode pengamatan dikurangi 1 .

$$
\sigma \mathrm{Ri}, \mathrm{Rj}=\sum_{i j=1}^{n} \frac{[(R i t-E(R i) .(R j t-E(R j)]}{n}
$$

Keempat, menghitung kovarian antar saham dari masing-masing perusahaan sampel, yaitu perkalian antara pengurangan return saham dengan expected return pada masing-masing saham dibagi dengan jumlah periode pengamatan. 


$$
E(R p)=\sum_{t=1}^{N} W i \cdot E(R i)
$$

Keenam, menghitung expected return portofolio yang dihasilkan dari jumlah perkalian antara proporsi dengan return saham.

$$
\sigma \varrho=\sqrt{\sum_{i-1}^{n} \sum_{j-1}^{n} W i W j \sigma i j}
$$

Ketujuh, menghitung standar deviasi portofolio yang dihasilkan dari perkalian matriks antara matriks covarian dengan matriks proporsi antar masing-masing saham. Selanjutnya, menghitung $E(R p)$ dan op yang optimal dengan meminimumkan nilai varians dan memakai fungsi objektif.

Ada tiga kendala yang dapat dipasangkan untuk mencapai portofolio optimal dengan risiko terkecil model Markowitz. Pertama, $\sum_{i=1}^{n} w i=1$, total proporsi pada setiap aktiva yang diinvestasikan sama dengan 1 atau 100\%. Kedua, nilai proporsi dari setiap saham tidak boleh bernilai negatif ( 0 untuk i $=1$ sampai dengan $\mathrm{n}$ ). Ketiga, $\sum_{i=1}^{n} w i . R i=R p$, jumlah rata-rata dari seluruh return masing-masing saham (Ri) sama dengan return portofolio. Model penyelesaian optimasi sebagai berikut ini:

$$
\text { Minimumkan } \sum_{i=1}^{n} w i . \sigma i^{2}+\sum_{i-1}^{n} \sum_{j=1}^{n} w i \cdot w j . \sigma_{i j}
$$

\section{Pengukuran Kinerja Portofolio dengan menggunakan M etode Sharpe Ratio}

M etode Sharpe biasa digunakan untuk investor yang menggunakan dananya hanya atau sebagian besar pada portofolio tersebut, sehingga risiko portofolio dinyatakan standar deviasi. M enurut Halim (2015), persamaan tersebut dapat dihitung sebagai berikut:

$$
S_{p}=\frac{R_{p}-R_{f}}{\sigma_{p}}
$$

Berdasarkan rumus di atas, Sharpe ratio dihasilkan dari return portofolio dikurangi dengan tingkat suku bunga bebas risiko dibagi dengan standar deviasi portofolionya. Kemudian, berdasarkan hasil penelitian yang dilakukan oleh Paryanti \& Lestari (2016) menunjukkan bahwa hasil tertinggi didapatkan dengan menggunakan metode Sharpe sehingga metode ini dianggap lebih efektif dalam pengukuran atau penilaian kinerja portofolio saham yang dapat diminimalkan dalam seluruh risiko yang ada secara sistematik atau secara tidak sistematis dalam kombinasi portofolio saham. Maka dalam penelitian ini peneliti menggunakan metode Sharpe dalam mengukur kinerja portofolio dari Jakarta Islamic Index (JII) dan IDX30. Penelitan lainnya yang mendukung yang dilakukan oleh Puspita \& Purnawati (2019), yaitu melakukan pengukuran kinerja portofolio dengan menggunakan metode Sharpe ratio.

$\mathrm{H}_{1}$ : terdapat perbedaan kinerja portofolio saham antara portofolio Jakarta Islamic Index (JII) dan portofolio IDX30.

\section{METODE PENELITIAN}

Jenis penelitian yang digunakan adalah penelitian verifikatif dengan metode explanatory survey dan menggunakan teknik statistik komparatif. Objek penelitiannya adalah kinerja portofolio Jakarta Islamic 
Index (III) dan IDX30 dengan menggunakan metode Sharpe ratio. Unit analisis yang digunakan adalah organisasi, dengan mengambil data saham yang terdaftar pada Jakarta Islamic Index (JII) dan IDX30 periode 2016-2018 di Bursa Efek Indonesia. Lokasi penelitiannya ialah tiga puluh perusahaan pada Jakarta Islamic Index (JII) dan tiga puluh perusahaan pada IDX30 yang terdaftar di Bursa Efek Indonesia dengan pengambilan data pada situs resmi Bursa Efek Indonesia. Jenis data yang digunakan adalah data kuantitatif. Sumber data yang digunakan adalah data sekunder berupa daftar harga saham (closing price) yang tergabung di Jakarta Islamic Index (JII), IDX30, data IHSG dan tingkat suku bunga yang berasal dari situs resmi Bank Indonesia dan Bursa efek Indonesia. Metode penarikan sampel yang digunakan pada penelitian ini adalah purposive sampling dengan kiteria sebagai berikut: (1) sahamsaham yang masuk ke dalam Jakarta Islamic Index (III) dan indeks IDX30 selama periode 2016-2018; (2) memiliki ketersediaan catatan harga saham harian dalam kurun waktu dilaksanakannya penelitian; (3) saham-saham yang menghasilkan expected return bernilai positif. Berdasarkan kriteria pengambilan sampel maka diperoleh sample sebanyak 189 perusahaan pada Jakarta Islamic index (JII) dan dua ratus perusahaan pada IDX30.

Tabel 1. Operasional Variabel

\begin{tabular}{|c|c|c|c|}
\hline Variabel & Indikator & Ukuran & Skala \\
\hline $\begin{array}{l}\text { Expected } \\
\text { Return } \\
\text { Portofolio }\end{array}$ & $\begin{array}{l}\text { Expected return portofolio } \\
\text { JII } \\
\text { Expected return portofolio } \\
\text { IDX30 }\end{array}$ & $E(R p)=\sum_{t=1}^{N} W i \cdot E(R i)$ & Rasio \\
\hline $\begin{array}{l}\text { Risk Free } \\
\text { Rate }\end{array}$ & $\begin{array}{l}\mathrm{BI} \text { rate dan BI 7-Day (Reserve) } \\
\text { Repo Rate (RF) per kuartal } \\
\text { periode 2016-2018 }\end{array}$ & $\begin{array}{l}\text { Risk free rate diproksi dengan suku } \\
\text { bunga SBI (Sertifikat Bank Indonesia) } \\
\text { dan BI 7- Days (Reserve) Repo Rate }\end{array}$ & Rasio \\
\hline $\begin{array}{l}\text { Standar } \\
\text { Deviasi } \\
\text { Portofolio }\end{array}$ & $\begin{array}{l}\text { Standar deviasi portofolio JII } \\
\text { Standar deviasi portofolio } \\
\text { IDX30 }\end{array}$ & $\begin{array}{l}\sigma Q \\
=\sqrt{ } \sum_{i-1}^{n} \sum_{j-1}^{n} W i W j \sigma i j\end{array}$ & Rasio \\
\hline $\begin{array}{l}\text { Indeks } \\
\text { Sharpe }\end{array}$ & $\begin{array}{l}\text { Sharpe Ratio JII } \\
\text { Sharpe Ratio IDX30 }\end{array}$ & $S_{P}=\frac{R_{p}-R_{f}}{\sigma_{p}}$ & Rasio \\
\hline
\end{tabular}

Dalam penelitian ini data sekunder diperoleh dengan mengunduh data harga saham Jakarta Islamic Index (JII) dan indeks IDX30 periode 2016-2018 dan data IHSG selama periode penelitian dari Bursa Efek Indonesia melalui laman Yahoo Finance dan Bursa Efek Indonesia, tingkat bunga bebas risiko (BI Rate 7-Days (Reserve) Repo rate) dan data bulanan Suku Bunga Sertifikat Indonesia (SBI) melalui laman Bank Indonesia. Pengolahan data menggunakan metode Markowitz dengan pendekatan minimum variance, analisis data menggunakan dua pengujian, yaitu uji data dengan menguji normalitas data, dan homogenitas data serta pengujian beda dengan pengujian independent sample t-test.

\section{HASIL DAN PEMBAHASAN}

Dalam pembentukan portofolio optimal dengan menggunakan metode Markowitz, saham yang diperhitungkan ke dalam perhitungan portofolio adalah saham yang memiliki expected return ( $E(R i))$ bernilai positif pada setiap periode pembentukan portofolio. Berikut merupakan jumlah emiten yang termasuk kriteria pemilihan sampel menggunakan metode M arkowitz. 
Tabel 2. Jumlah Emiten yang Termasuk ke Dalam Perhitungan Portofolio dengan Metode Markowitz

\begin{tabular}{cccccccccccccc}
\hline \multirow{2}{*}{ Indeks } & \multicolumn{4}{c}{$\mathbf{2 0 1 6}$} & \multicolumn{1}{c}{$\mathbf{2 0 1 7}$} & \multicolumn{1}{c}{$\mathbf{2 0 1 8}$} & \multirow{2}{*}{ Total } \\
\cline { 2 - 14 } & Q1 & Q2 & Q3 & Q4 & Q1 & Q2 & Q3 & Q4 & Q1 & Q2 & Q3 & Q4 & \\
\hline JII & 23 & 18 & 21 & 8 & 19 & 13 & 12 & 16 & 16 & 8 & 15 & 20 & 189 \\
IDX30 & 23 & 18 & 20 & 7 & 24 & 20 & 11 & 21 & 11 & 6 & 20 & 19 & 200 \\
\hline
\end{tabular}

Pembentukan Portofolio Optimal dengan Minimum Variance pada Jakarta Islamic Index (JII) dan IDX30

Berdasarkan Tabel 3, pada Jakarta Islamic Index (JII) jumlah emiten yang masuk ke dalam perhitungan portofolio optimal dari total emiten 360 adalah sebanyak 189 saham maka jumlah emiten yang tidak masuk ke dalam perhitungan portofolio optimal adalah sebanyak 171 emiten. Pada IDX30, jumlah emiten yang masuk ke dalam perhitungan portofolio optimal dari total emiten 360 adalah sebanyak dua ratus saham maka jumlah emiten yang tidak masuk ke dalam perhitungan portofolio optimal adalah sebanyak 160 emiten. Dalam melakukan perhitungan ini, terlebih dahulu menentukan proporsi dana (Wi) pada masing-masing sampel yang membentuk portofolio saham dengan total proporsi $100 \%$ yang kemudian hasil ini diminimumkan nilai variansnya dengan memakai fungsi objektif untuk mendapatkan proporsi yang optimal.

Tabel 3. E(Rp) dan oppada Jakarta Islamic Index (III) Periode Kuartal 1-4 Tahun 2016-2018

\begin{tabular}{lcll}
\hline Periode & Jumlah Saham & RP & SDP \\
\hline Q1 2016 & 23 & $0,150 \%$ & $0,710 \%$ \\
Q2 2016 & 18 & $0,260 \%$ & $0,710 \%$ \\
Q3 2016 & 21 & $0,120 \%$ & $1,030 \%$ \\
Q4 2016 & 8 & $0,150 \%$ & $1,290 \%$ \\
Q1 2017 & 19 & $0,100 \%$ & $0,490 \%$ \\
Q2 2017 & 13 & $0,140 \%$ & $0,630 \%$ \\
Q3 2017 & 12 & $0,090 \%$ & $0,660 \%$ \\
Q4 2017 & 16 & $0,160 \%$ & $0,640 \%$ \\
Q1 2018 & 16 & $0,180 \%$ & $1,170 \%$ \\
Q2 2018 & 8 & $0,190 \%$ & $1,210 \%$ \\
Q3 2018 & 15 & $0,120 \%$ & $1,150 \%$ \\
Q4 2018 & 20 & $0,180 \%$ & $0,780 \%$ \\
\hline
\end{tabular}

Berdasarkan Tabel 4, dapat kita ketahui bahwa semakin banyak aset dalam sebuah portofolio maka risiko sistematis yang tersebar akan semakin rendah, terlihat pada kuartal satu (Q1) tahun 2017 yang menghasilkan standar deviasi terendah senilai 0,490\% per kuartal dengan jumlah saham sebanyak sembilan belas saham. Kemudian, jika aset dalam sebuah portofolio semakin sedikit, risiko sistematis yang tersebar akan makin tinggi, terlihat pada kuartal empat (Q4) tahun 2016 yang menghasilkan standar deviasi tertinggi sebesar 1,290\% per kuartal dengan jumlah saham dalam portofolio sebanyak delapan saham. 
Tabel 4. E(Rp) dan oppada IDX30 Periode Kuartal 1-4 Tahun 2016-2018

\begin{tabular}{cccc}
\hline Periode & Jumlah Saham & RP & SDP \\
\hline Q1 2016 & 23 & $5,360 \%$ & $0,780 \%$ \\
Q2 2016 & 18 & $0,120 \%$ & $0,720 \%$ \\
Q3 2016 & 20 & $0,210 \%$ & $0,890 \%$ \\
Q4 2016 & 7 & $0,120 \%$ & $1,390 \%$ \\
Q1 2017 & 24 & $0,120 \%$ & $0,490 \%$ \\
Q2 2017 & 20 & $0,120 \%$ & $0,550 \%$ \\
Q3 2017 & 11 & $0,130 \%$ & $0,590 \%$ \\
Q4 2017 & 21 & $0,180 \%$ & $0,620 \%$ \\
Q1 2018 & 11 & $0,130 \%$ & $0,910 \%$ \\
Q2 2018 & 6 & $0,060 \%$ & $0,990 \%$ \\
Q3 2018 & 20 & $0,140 \%$ & $0,990 \%$ \\
Q4 2018 & 19 & $0,180 \%$ & $0,830 \%$ \\
\hline
\end{tabular}

Dapat kita ketahui bahwa makin banyak aset dalam sebuah portofolio maka risiko sistematis yang tersebar akan makin rendah, terlihat pada kuartal 1 (Q1) tahun 2017 yang menghasilkan standar deviasi terendah senilai $0,490 \%$ perkuartal dengan jumlah saham sebanyak 24 saham. Kemudian, jika aset dalam sebuah portofolio semakin sedikit maka risiko sistematis yang tersebar akan semakin tinggi, terlihat pada kuartal dua (Q2) tahun 2018 yang menghasilkan standar deviasi tertinggi sebesar 1,390\% perkuartal dengan jumlah saham dalam portofolio sebanyak tujuh saham.

\section{Penentuan Kinerja Portofolio Saham dengan Metode Sharpe Ratio}

Setelah dilakukan perhitungan portofolio optimal pada Jakarta IsImic Index (JII) dan IDX30 periode 2016-2018, maka selanjutnya dilakukan perhitungan kinerja portofolio saham dengan menggunakan metode Sharpe ratio yang merupakan hasil dari return portofolio dikurangi risk free kemudian dibagi dengan standar deviasi portofolionya.

Tabel 5. Sharpe Ratio Jakarta IsImic Index (JII) dan IDX30 Periode Kuartal 1-4 pada Tahun 2016-2018

\begin{tabular}{ccccc}
\hline Periode & SR JII & $\begin{array}{c}\text { Rata-rata SR JII } \\
\text { pertahun }\end{array}$ & SR IDX30 & $\begin{array}{c}\text { Rata-rata SR } \\
\text { JI pertahun }\end{array}$ \\
\hline Q1 2016 & 0,180 & & 0,030 & \\
Q2 2016 & 0,340 & 0,180 & 0,140 & 0,120 \\
Q3 2016 & 0,100 & & 0,220 & \\
Q4 2016 & 0,100 & & 0,080 & \\
Q1 2017 & 0,180 & & 0,210 & \\
Q2 2017 & 0,210 & \multirow{2}{*}{0,180} & 0,210 & 0,220 \\
Q3 2017 & 0,110 & & 0,210 & \\
Q4 2017 & 0,230 & & 0,270 & \\
Q1 2018 & 0,140 & & 0,130 & \\
Q2 2018 & 0,150 & & 0,050 & 0,130 \\
Q3 2018 & 0,090 & 0,150 & 0,120 & \\
Q4 2018 & 0,220 & & 0,200 & \\
\hline
\end{tabular}


Dari hasil perhitungan Sharpe ratio di Jakarta Islamic Index (JII) dan IDX30 secara merata dari setiap periodenya bernilai positif. Hal ini disebabkan karena return portofolio yang dihasilkan lebih besar dibandingkan dengan risiko portofolionya. Hal ini menunjukkan bahwa dalam portofolio Jakarta Islamic Index (JII) dan IDX30 selalu menunjukkan kinerja yang bernilai positif atau baik.

\section{Pengujian Hipotesis}

Uji Normalitas Data

Uji Normalitas data dilakukan sebelum melakukan uji hipotesis, uji normalitas data menggunakan One Sample Kolomogrov-Smirnov Test.

Tabel 6. Hasil Uji Normalitas pada Sharpe Ratio Jakarta Islamic Index (JII) dan IDX30

\begin{tabular}{lccc}
\hline & \multicolumn{3}{c}{ Kolmogorov-Smirnov } \\
\cline { 2 - 4 } Sharpe Ratio & Statistic & Df & Sig. \\
\cline { 2 - 4 } SR JII & 0,220 & 12 & 0,111 \\
SR IDX & 0,133 & 12 & 0,200 \\
\hline
\end{tabular}

Hasil uji normalitas di atas menunjukkan bahwa data Sharpe ratio di Jakarta Islamic Index (JII) dan IDX30 yang digunakan dalam penelitian ini berdistribusi secara normal. Hal ini diperlihatkan oleh nilai signifikasi dari JII dan IDX lebih besar daripada ( $\alpha=5 \%$ ) yaitu nilai signifikasi JII sebesar 0,111 >0,05 dan nilai signifikasi IDX sebesar 0,200 >0,050.

\section{Uji Homogenitas Data}

Setelah melakukan uji normalitas data, selanjutnya adalah uji homogenitas data. Dalam statistik uji homogenitas digunakan untuk mengetahui varian dari beberapa populasi sama atau tidak.

Tabel 7. Uji Homogenitas pada Sharpe Ratio di Jakarta Islamic Index (JII) dan IDX30

\begin{tabular}{cccc}
\hline Levene Statistic & df1 & df2 & Sig. \\
\hline 0,270 & 1 & 22 & 0,609 \\
\hline
\end{tabular}

Hasil Homogenitas di atas dapat dinilai dari nilai sig. pada tabel Levene Statistic bahwa nilai sig. lebih besar dari 0,050 yaitu sebesar 0,609 >0,050. Artinya, bahwa data tersebut dinyatakan homogen, karena memiliki varian yang sama.

\section{Uji Beda Independent Sample T-test}

Uji beda yang akan digunakan dalam penelitian ini adalah uji beda independent sample t-test.

Tabel 8. Uji beda Independent Sample T-test

\begin{tabular}{lccccc}
\hline \multicolumn{2}{c}{ Sharpe Ratio } & N & Mean & Std. Deviation & $\begin{array}{c}\text { Std. Error } \\
\text { Mean }\end{array}$ \\
\hline Nilai & SR JII & 12 & 0,156 & 0,076 & 0,022 \\
& SR IDX & 12 & 0,171 & 0,073 & 0,021 \\
\hline
\end{tabular}

Berdasarkan data grup statistik tersebut, nilai rata-rata dapat diketahui berdasarkan mean dapat disimpulkan bahwa rata-rata sharpe ratio JII memiliki nilai sebesar 0,1558 dan rata-rata sharpe ratio IDX sebesar 0,1708. Hal ini menunjukkan bahwa rata-rata pada Sharpe ratio IDX30 lebih besar daripada Sharpe ratio JII. 
Ami Adawiyah: Perbandingan Kinerja Portofolio ...

Tabel 9. Uji beda Sharpe Ratio Jakarta Islamic Index (III) dan IDX30 menggunakan Uji Beda Independent Sample T-test

\begin{tabular}{|c|c|c|c|c|c|c|}
\hline & \multicolumn{2}{|c|}{$\begin{array}{c}\text { Levene's Test for } \\
\text { Equality of Variances }\end{array}$} & \multicolumn{3}{|c|}{ t-test for Equality of Means } \\
\hline & & $\mathbf{F}$ & Sig. & $\mathbf{t}$ & Df & Sig. (2-tailed) \\
\hline \multirow{2}{*}{ Nilai } & Equal variances assumed & 0,270 & 0,610 & $-0,496$ & 22 & 0,625 \\
\hline & Equal variances not assumed & & & $-0,496$ & 22 & 0,625 \\
\hline
\end{tabular}

Berdasarkan hasil uji beda yang ditunjukkan pada tabel di atas, angka sig. (2-tailed) sebesar 0,625 $>0,050, \alpha=5 \%$ Dengan demikian, maka Ho diterima dan Ha ditolak, yang menyatakan tidak terdapat perbedaan Sharpe ratio Jakarta Islamic Index (JII) dengan Sharpe ratio IDX30 .

\section{HASIL DAN PEMBAHASAN \\ Pembentukan Portofolio Optimal dengan Minimum Variance pada Jakarta Islamic Index (JII) dan IDX30.}

Pembentukan portofolio optimal dalam penelitian ini yaitu dengan menggunakan minimum variance, portofolio optimal dengan varian minimum dapat memberikan risiko terkecil pada tingkat return tertentu. Data harga saham yang digunakan merupakan harga saham harian dengan periode pembentukan portofolio optimal ialah per kurtal di mana ada empat kuartal pada setiap tahunnya. Berdasarkan hasil optimasi yang telah dilakukan pada Jakarta Islamic Index, jika dilihat dari sisi saham secara individual, saham ICBP secara konsisten masuk dalam perhitungan portofolio dan tiga kali menempati peringkat kesatu selama periode kuartal satu sampai empat tahun 2016-2018. Kemudian hasil optimasi yang telah dilakukan pada IDX30 terdapat satu saham yang secara konsisten masuk dalam perhitungan portofolio dan enam kali menempati peringkat kesatu selama periode kuartal satu sampai empat tahun 2016-2018 yaitu saham BBCA dan saham BBCA ini merupakan saham dengan kategori nonsyariah sehingga masuk ke dalam indeks IDX30, tetapi tidak termasuk ke dalam Jakarta Islamic Index (JII).

Hasil analisis dari 24 portofolio yang terbentuk dari Jakarta Islamic Index (JII) dan IDX30 selama tahun 2016-2018 per kuartal menunjukkan bahwa dari dua belas periode perhitungan yaitu dari kuartal satu sampai empat tahun 2016-2018, IDX30 memiliki enam periode return portofolio yang lebih besar dari Jakarta Islamic Index (JI) sedangkan Jakarta Islamic Index (JII) memiliki lima periode return portofolio yang lebih besar dari IDX30. Karena pada periode terakhir yaitu kuartal empat tahun 2018, return portofolio kedua indeks tersebut menghasilkan nilai yang sama maka dapat disimpulkan bahwa return portofolio IDX30 lebih unggul dari return portofolio JII. Hal ini disebabkan karena saham-saham dengan bobot tertinggi adalah saham-saham perbankan yang tergabung dalam IDX30.

Hasil pengolahan standar deviasi portofolio tertinggi IDX30 sebesar 1,390\% perkuartal (kuartal empat tahun 2016) dengan jumlah saham dalam portofolio hanya tujuh saham saja. Hal ini karena jumlah saham dalam perhitungan portofolio pada periode ini hanya sedikit. Artinya, risiko dapat diminimalisir dengan membentuk sebuah portofolio di mana dapat dilakukan dengan menggabungkan berbagai aset di dalamnya, seperti menurut Andriyani (2016), standar deviasi portofolio tertinggi Jakarta Islamic Index (JII) sebesar 1,290\% per kuartal dengan jumlah saham sebanyak delapan saham (kuartal empat tahun 2016). Risiko portofolio yang di tanggung oleh portofolio IDX30 lebih besar jika dibandingkan dengan risiko Jakarta Islamic Index (JII). Hal ini disebabkan saham-saham yang tergabung dalam IDX30 sebagian besar adalah saham perbankan di mana tingkat inflasi, suku bunga, mata uang 
serta tingkat likuiditas menyebabkan saham-saham ini memiliki risiko yang tinggi. Return portofolio Jakarta Islamic Index (III) dan IDX30 mampu menghasilkan nilai return portofolio positif pada saat return market bernilai negatif.

Tabel 10. Return dan Standar Deviasi IHSG periode kuartal 1-4 tahun 2016-2018

\begin{tabular}{lcccc}
\hline Periode & ER(m) & $\begin{array}{c}\text { Rata-rata } \\
\text { ER(m) } \\
\text { pertahun }\end{array}$ & SD(m) & $\begin{array}{c}\text { Rata-rata SD(m) } \\
\text { pertahun }\end{array}$ \\
\hline Q1 2016 & $0,080 \%$ & & $0,780 \%$ & \\
Q2 2016 & $0,130 \%$ & $0,061 \%$ & $0,750 \%$ & $0,834 \%$ \\
Q3 2016 & $0,060 \%$ & & $0,830 \%$ & \\
Q4 2016 & $-0,030 \%$ & & $0,970 \%$ & \\
Q1 2017 & $0,120 \%$ & & $0,470 \%$ & \\
Q2 2017 & $0,050 \%$ & $0,091 \%$ & $0,640 \%$ & $0,550 \%$ \\
Q3 2017 & $0,050 \%$ & & $0,470 \%$ & \\
Q4 2017 & $0,150 \%$ & & $0,620 \%$ & \\
Q1 2018 & $-0,150 \%$ & & $0,890 \%$ & \\
Q2 2018 & $-0,010 \%$ & $-0,003 \%$ & $1,180 \%$ & $0,979 \%$ \\
Q3 2018 & $-0,020 \%$ & & $1,130 \%$ & \\
Q4 2018 & $0,170 \%$ & & $0,720 \%$ & \\
\hline
\end{tabular}

Dapat dilihat pada Tabel 10, pada kuartal empat tahun 2016, kuartal satu sampai dengan tiga tahun 2018, IHSG menghasilkan return market bernilai negatif. Hal ini menandakan bahwa pada periode tersebut kondisi pasar sedang mengalami penurunan, tetapi indeks JII dan IDX30 mampu memberikan return portofolio bernilai positif. Hal ini menunjukkan bahwa pembentukan portofolio optimal dengan minimum variance mampu menghasilkan risiko portofolio terkecil pada tingkat pengembalian tertentu dan juga dapat mengoptimalkan proporsi saham agar menghasilkan return positif pada saat return pasar mengalami penurunan atau bahkan pada kondisi di mana return market bernilai negatif. Return portofolio yang dihasilkan JII dan IDX30 pada setiap periode secara merata lebih besar dari tingkat suku bunga bebas risikonya. Artinya, return portofolio yang dihasilkan oleh kedua indeks ini lebih menguntungkan dibandingkan dengan tingkat return investasi pada suatu aset yang bebas risiko.

\section{Penentuan Kinerja Portofolio Saham dengan M etode Sharpe Ratio Pada Jakarta Islamic Index (JII) dan IDX30}

Dari hasil analisis dari nilai Sharpe ratio, Jakarta Islamic Index (JII) memberikan kinerja yang lebih konsisten dengan memiliki enam periode dengan nilai SR yang lebih besar dibandingkan IDX30 sedangkan IDX30 hanya memiliki lima periode dengan nilai SR yang lebih besar dari Jakarta Islamic Index (JII) dan pada satu periode yang sama JII dan IDX30 memiliki hasil yang sama. Dengan demikian maka dapat disimpulkan bahwa selama periode penelitian Jakarta Islamic Index (JII) mampu menghasilkan kinerja yang lebih unggul dibandingkan IDX30, karena saham-saham yang tergabung ke dalam IDX30 sebagian besar merupakan saham-saham perbankan yang memiliki tingkat risiko tinggi. Dengan demikian risiko yang di tanggung oleh portofolio saham JII lebih kecil jika dibandingkan dengan IDX30.

Setelah dilakukan perhitungan return portofolio, risiko portofolio dan kinerja portofolio, dapat diketahui bahwa return portofolio yang dihasilkan IDX30 lebih unggul dibandingkan Jakarta Islamic Index 
(III) akan tetapi dari sisi kinerja yang dihasilkan Jakarta Islamic Index (III) lebih unggul dari IDX30. Hal ini terjadi karena IDX30 merupakan index yang didominasi oleh saham-saham perbankan di mana saham perbankan tersebut menyumbang bobot yang tinggi dengan risiko yang lebih tinggi.

\section{Pengujian Hipotesis}

Berdasarkan hasil Uji Beda Independent Sample T-test, dapat diketahui bahwa nilai signifikasi lebih besar dari taraf signifikasi $\alpha=5 \%$ dengan melihat hasil nilai sig. (2-tailed) sebesar 0,625 $>0,050$. Maka kesimpulan hipotesis yang dapat diambil yaitu Ho diterima dan Ha ditolak yang berarti bahwa tidak terdapat perbedaan antara Sharpe ratio Jakarta Islamic Index (JII) dan Sharpe ratio IDX30 atau kinerja portofolio Jakarta Islamic Index (JII) dengan kinerja portofolio IDX30 adalah sama.

Tabel 11. Kapitalisasi Pasar JII dan IDX30 periode 2014-2018

\begin{tabular}{clr}
\hline Tahun & JII (Rupiah) & \multicolumn{1}{c}{ IDX (Rupiah) } \\
\hline $\mathbf{2 0 1 4}$ & 64.817 .723 .523 .268 & 95.763 .145 .157 .237 \\
$\mathbf{2 0 1 5}$ & 58.124 .103 .046 .746 & 88.739 .523 .191 .727 \\
$\mathbf{2 0 1 6}$ & 67.648 .936 .404 .347 & 102.564 .372 .160 .104 \\
$\mathbf{2 0 1 7}$ & 94.013 .062 .650 .408 & 165.056 .019 .679 .872 \\
$\mathbf{2 0 1 8}$ & 75.784 .000 .093 .098 & 145.182 .885 .664 .289 \\
Rata-Rata & 72.077 .565 .143 .574 & 119.461 .189 .170 .646 \\
\hline
\end{tabular}

Penyebab tidak adanya perbedaan antara kedua indeks tersebut dikarenakan kiteria pemilihan saham yang sama yaitu saham-saham yang memiliki tingkat likuiditas terbaik dan kapitalisasi pasar yang besar hal ini terbukti dari beberapa anggota Jakarta Islamic Index (JII) juga merupakan anggota IDX30 seperti saham-saham berikut yang konsisten masuk ke dalam indeks JII dan IDX30 selama tahun 20162018, yaitu saham ADRO, ASII, BSDE, ICBP, INDF, KLBF, LPPF, PGAS, SM GR, TLKM, UNTR, dan UNVR. Perbedaan di antara anggota kedua indeks tersebut yaitu terletak pada Jakarta Islamic Index (III) yang dalam pemilihan kiteria anggota sahamnya hanya saham-saham yang memenuhi prinsip syariah dan kapitalisasi pasar yang dihasilkan oleh IDX30 sepanjang tahun 2014-2018 sebesar Rp119.461.189.170.646 lebih besar dibandingkan kapitalisasi pasar yang dihasilkan oleh Jakarta Islamic Index (JII) sebesar Rp72.077.565.143.574. Dapat disimpulkan bahwa meskipun indeks dengan kategori syariah memiliki nilai kapitalisasi pasar yang lebih kecil dari indeks nonsyariah tetapi dilihat dari sisi kinerja portofolionya, indeks dengan kategori syariah memiliki kinerja portofolio yang sama dengan indeks dengan kategori nonsyariah.

\section{KESIMPULAN}

Berdasarkan hasil pembahasan yang telah dilakukan, maka peneliti memperoleh simpulan (1) Sharpe Ratio yang dihasilkan pada portofolio Jakarta Islamic Index (JII) dan IDX30 pada setiap periodenya bernilai positif, hal ini menunjukkan bahwa dalam portofolio kedua indeks selalu menunjukkan kinerja yang baik. Portofolio Jakarta Islamic Index (JII) pada setiap periode menghasilkan kinerja yang lebih unggul dibandingkan portofolio IDX30, karena risiko portofolio yang di tanggung Jakarta Islamic Index (III) lebih kecil dibandingkan dengan risiko IDX30. Return portofolio yang dihasilkan IDX30 lebih unggul dari return portofolio Jakarta Islamic Index (JII) dikarenakan pada kombinasi portofolio optimal IDX30 didominasi oleh saham-saham perbankan seperti BBCA, BMRI, BBNI, BBRI di mana saham-saham perbankan tersebut menyumbang bobot yang besar untuk IDX30. (2) Berdasarkan hasil uji beda independen sample t-test menunjukkan bahwa tidak terdapat perbedaan antara kinerja portofolio Jakarta Islamic Index (JII) dengan kinerja portofolio IDX30, dengan demikian Ho diterima dan Ha ditolak. 
Hal ini memberikan implikasi bahwa tidak ada return tambahan yang dapat diperoleh investor dengan cara membedakan saham yang memiliki kiteria syariah dengan yang bukan syariah.

\section{DAFTAR PUSTAKA}

Andriani, P., \& Suprihhadi, H. (2015). Optimalisasi Portofolio Optimal Model Indeks Tunggal pada Perusahaan Property dan Real Estate. Jurnal IImu dan Riset M anajemen (JIRM ), 4(11), 1-17.

Dahlan, S., Topowijono, \& Zahroh, Z.A. (2013). Penggunaan Single Index Model Dalam Analisis Portofolio untuk Meminimumkan Risiko Bagi Investor di Pasar Modal (Studi Pada Saham Perusahaan yang Tercatat Dalam Indeks LQ-45 Di Bursa Efek Indonesia Periode 2010-2012). Jurnal Administrasi Bisnis, 6(2), 1-10.

Fahmi, I. (2015). Pengantar Teori Portofolio dan Analisis Investasi. Bandung: Alfabeta.

Halim, A. (2015). Analisis Investasi di Asset Keuangan. Bogor: Mitra Wacana M edia.

Hartono, J. (2017). Teori portofolio dan Analisis Investasi. Yogyakarta: Penerbit BPFE.

Larasati, D., Irwanto, A. K., Permanasari, Y. (2013). Analisis Strategi Optimalisasi Portofolio Saham LQ 45 (Pada Bursa Efek Indonesia Tahun 2009-2011). Jurnal Manajemen dan Organisasi, 4(2). 163-171.

Lee, H. S., Cheng , F. F., \& Chong, S. C. (2015). Markowitz Portfolio Theory and Capital Asset Pricing Model for Kuala Lumpur Stock Exchange. International Journal of Economics and Financial Issues, 6(12), 59-66.

Natalia, E., Darminto, \& Endang W. (2014). Penentuan Portofolio Saham yang Optimal Dengan Model Markowitz Sebagai Dasar Penetapan Investasi Saham (Studi pada Perusahaan Food and Beverage yang Terdaftar di Bursa Efek Indonesia Tahun 2012). Jurnal Administrasi Bisnis, 9(1), 1-9.

Paryanti, A. B., \& Lestari, S. (2016). Analisis Penilaian Kinerja Portofolio Saham Dengan Menggunakan Metode Sharpe Measure Dan Treynor Measure Pada Saham-Saham Indeks Sektoral Yang Terdaftar Di Bursa Efek Indonesia (BEI) Periode 2008-2010. Jurnal CKI On SPOT, 9(1), 29-46.

Rifaldy, A. \& Sedana, I.B.P. (2016). Optimasi Portofolio Saham Bisnis 27 Di Bursa Efek Indonesia (Pendekatan M odel M arkowitz). E-Jurnal M anajemen Unud, 5(3), 1657-1689.

Rumintang, A.G.\& Azhari, M. (2014). Analisis Perbandingan Kinerja Reksadana Sham Konvensional Dan Reksadana Saham Syariah Dengan Menggunakan Metode Sharpe, Treynor, and Jensen Pada Tahun 2014. e- Proceeding of M anagement, 2(2), 1428-1435.

Sirucek, M.\& Lukas, K. (2015). Application of Markowitz Portofolio Theory by Building Optimal Portfolio on the Us Stock Market. Acta Universitatis Agriculturae Et Silviculturae M endelianae Brunensis, 6(3), 1375-1386. http://dx.doi.org/10.11118/actaun201563041375

Setyawati, N.P.E.C., \& Sudiartha, G.M. (2019). Pembentukan Portofolio Optimal Menggunakan Model Markowitz. E-Jurnal M anajemen, 8(7), 4213-4238.

Sutan, E. K. (2018, April 6), Kapitalisasi Pasar. Saham Oke. https://www.sahamok.net/emiten/kapitalisasi-pasar/

Chandra, L., \& Hapsari, Y. D. (2013). Analisis Pembentukan Portofo Optimal Dengan Menggunakan M odel M arkowitz Untuk Saham LQ 45 Periode 2008-2012. Jurnal M anajemen, 1(1), 41-65.

Tuerah,C. (2013). Perbandingan Kinerja Saham LQ45 Tahun 2012 M enggunakan M etode Jensen, Sharpe, Dan Treynor. Jurnal Riset Ekonomi, Manajemen, Bisnis dan Akuntansi, 1(4), 1444-1457. 
